\title{
"In the best interests of the child": Mapping the (re) emergence of pro-adoption politics in contemporary australia
}

Murphy, Kate; Quartly, Marian; Cuthbert, Denise

https://researchrepository.rmit.edu.au/esploro/outputs/9921858420801341/filesAndLinks?institution=61RMIT_INST\&index=null

Murphy, K., Quartly, M., \& Cuthbert, D. (2009). "In the best interests of the child": Mapping the (re) emergence of pro-adoption politics in contemporary australia. Australian Journal of Politics and History, 55(2), 201-218. https://doi.org/10.1111/j.1467-8497.2009.01516a.x

Document Version: Submitted Version

Published Version: https://doi.org/10.1111/j.1467-8497.2009.01516a.x

Repository homepage: https://researchrepository.rmit.edu.au (c) 2009 School of History, Philosophy, Religion and Classics, School of Political Science and International Studies, University of Queensland and Blackwell Publishing Asia Pty Ltd

Downloaded On 2023/04/26 21:55:40 +1000 
Thank you for downloading this document from the RMIT Research Repository.

The RMIT Research Repository is an open access database showcasing the research outputs of RMIT University researchers.

RMIT Research Repository: http://researchbank.rmit.edu.au/

\section{Citation:}

Murphy, K, Quartly, M and Cuthbert, D 2009, "'In the best interests of the child": Mapping the (re) emergence of pro-adoption politics in contemporary Australia', Australian Journal of Politics and History, vol. 55, no. 2, pp. 201-218.

See this record in the RMIT Research Repository at:

http://researchbank.rmit.edu.au/view/rmit:19582

Version: Submitted Version

Copyright Statement: (c) 2009 School of History, Philosophy, Religion and Classics, School of Political Science and International Studies, University of Queensland and Blackwell Publishing Asia Pty Ltd

Link to Published Version:

http://researchbank.rmit.edu.au/view/rmit:19582 


\title{
"In the best interests of the child": Mapping the (re?) emergence of pro-adoption politics in contemporary Australia
}

\begin{abstract}
This article seeks to understand, in historical and international perspective, recent moves at an executive level to re-instate adoption as a viable policy option for the care and placement of children in Australia, with reference to two recent reports of the House of Representatives Standing Committee on Human and Family Services, Overseas Adoption in Australia: Report of the Inquiry into Adoption of Children from Overseas (2005), and The Winnable War on Drugs: The Impact of Illicit Drug Use on Families (2007) which raises adoption as a policy option for children of drug-addicted parents. These reports appear to signal a discursive shift away from the anti-adoption attitudes that have characterised the post-1970s period in response to the Stolen Generation and other past adoption practices. It is argued that this change can be understood in the context of the conservative family policy of the Howard era and international trends in adoption policy.
\end{abstract}

\section{Introduction}

In September 2007 the House of Representatives Standing Committee on Human and Family Services released its report The Winnable War on Drugs: The Impact of Illicit Drug Use on Families. The report made the news chiefly due to its controversial recommendation that the children of drug-addicted parents should be adopted. ${ }^{1}$ Chaired by Liberal MP Bronwyn Bishop, the inquiry specifically recommends that a

\footnotetext{
${ }^{1}$ Karen Collier, 'Radical plan for addict parents', The Herald Sun, 13 September, 2007 at http://www.news.com.au/heraldsun/story/0,21985,22412576-24331,00.html; Cath Hart, 'Forced adoption 'should be considered', The Australian, 13 September, 2007, at http://www.theaustralian.news.com.au/story/0,25197,22411450-5013404,00.html; 'Adopt out' the children of drug addicts, The Age, 13 September, 2007, at
} 
national adoption strategy should be implemented which recognises adoption as a way to give a "significant proportion" of children of drug-addicted parents a stable home. It is proposed that adoption should operate as the "default" care option for children aged under five, in cases in which illicit drug use is reported as a factor in a child protection notification. Where this is the case, it would fall on child protection authorities to prove that adoption was not in the "best interests" of the child/ren, reinforcing the implication that adoption would be naturalised under these proposed guidelines. ${ }^{2}$ Until very recently, such a proposal would have been virtually unthinkable. In an article published in July 2004, Rosemary Pringle observed that the “climate of apology” surrounding adoption in Australia, linked with understandable shame regarding past adoption practices and the “stolen generation” of Aboriginal children, meant that it had become “almost impossible” to endorse adoption as a policy option. ${ }^{3}$ This article seeks to understand, in historical and international perspective, the current moves at an executive level to re-instate adoption in Australia as a viable policy option for the care and placement of children; and within the social/cultural domain, to re-establish it as a valid way of "forming or adding to a family". 4

\section{Changing attitudes 1970s-1990s}

In 1996, the year the Howard government took office, adoption appeared to be thoroughly discredited both in public sentiment and as policy, due in large part to the

\footnotetext{
http://www.theage.com.au/news/NATIONAL/Adopt-out-the-children-of-drugaddicts/2007/09/13/1189276895859.html

${ }^{2}$ House of Representatives Standing Committee on Human and Family Services, The Winnable War on Drugs: The Impact of Illicit Drug Use on Families, September 2007, pp. xxii and ch. 3.

${ }^{3}$ Rosemary Pringle, 'Adoption in Britain: Reflexive Modernity?', Australian Feminist Studies, Vol. 19, 44 (July 2004), p. 225.

${ }^{4}$ Standing Committee on Human and Family Services, The Winnable War on Drugs, p. 84; House of Representatives Standing Committee on Human and Family Services, Overseas Adoption in Australia: Report of the Inquiry into Adoption of Children from Overseas, November 2005, p. 6.
} 
recognition (burgeoning in the 1970s and 1980s) of the damaging effects of previous adoption policies. The first adoption legislation in Australia, in the 1920s, had emphasised the importance of a "clean break" from birth parents and enshrined the principle of secrecy around the adoptive status of children, who were to be raised by their adoptive parents “as if born to them”. This principle was meant to provide adoptive parents with heirs without fear of stigma or interference from the biological parent/s, but also operated to allow the unmarried mother, her child, and her family, to be shielded from the shame of an "illegitimate" birth. The "clean break" principle was not relinquished readily: it was still being reiterated in legislation as late as 1965.5

However, by the 1970s a number of factors, including the complex social changes occasioned by feminism, saw adoption practices coming under challenge as the impacts of these policies, on both relinquishing mothers and adopted children, became better understood. The social stigma associated with unmarried motherhood was brought into question and ultimately reduced, in part as a result of the introduction of the Mother’s Benefit for single mothers (1973). This was part of a raft of legislative and administrative reforms by the Whitlam government which effectively redefined 'family' in Australian legal practice in the interests of women, children, and diversity. ${ }^{6}$ The growing cultural value placed on female agency created a climate in which the stories of unmarried mothers who had been coerced into adopting out their children could be told.

\footnotetext{
${ }^{5}$ Audrey Marshall and Margaret McDonald, The Many-Sided Triangle: Adoption in Australia (Carlton, Victoria, 2001), p. 99.

${ }^{6}$ This included reforms to marriage and divorce law. See Anne Summers, The Changing Family in a Changing World (Perth, W.A. 1985).
} 
In the ensuing public conversations about adoption, the voices of adopted adults and relinquishing mothers dominated, and adoption came to be viewed as the exploitation of young single mothers for the benefit of middle-class couples with fertility problems. ${ }^{7}$ As one adoptive mother commented on the change in popular attitudes to adoption that began to emerge in the 1970s, where once adoptive parents were seen as doing the "right" thing by way of the children they adopted, “adoption is now a dirty word". ${ }^{8}$ Throughout the 1990s and into the present decade, serial, harrowing revelations of the history of the parlous treatment of 'removed' children, whether indigenous, white Australian, or the British children who travelled here in imperial forced migration schemes well into the twentieth-century, had a profound impact on public perceptions of adoption. ${ }^{9}$ In the popular Australian imaginary, the trope of 'coming home', mobilised with great effect by indigenous Australians to account for their experiences of separation from family into institutions or adoption came to stand for the adoptive experience generally. This trope registers adoption as invariably entailing loss, removal from roots, and pain. Somewhat problematically, the 'coming home' trope also idealises the birth family, occludes the role and experiences of the adoptive family, and perpetuates potentially limiting essentialism in our understandings of 'family' and the role of the mother, in particular. Yet, it has and

\footnotetext{
${ }^{7}$ Marshall and McDonald, The Many-Sided Triangle, p. 10.

${ }^{8}$ Cited in Denise Cuthbert, "Mothering the 'Other': Feminism, Colonialism and the Experiences of Non-Aboriginal Adoptive Mothers of Aboriginal Children”, Balayi Vol. 1, 1 (2000), p. 35.

${ }^{9}$ Two inquiries and their associated reports, the Human Rights \& Equal Opportunity Commission's Bringing them Home: Report of the National Inquiry into the Separation of Aboriginal and Torres Strait Islander Children from Their Families (1997), and the Releasing the Past inquiry into adoption practices between 1950 and 1998 (2000), were instrumental in this change. Other relevant inquiries include the Australian Senate's Community Affairs Reference Committee's inquiry into Australians who experienced institutional or out-of-home care as children, the first report is Forgotten Australians (August 2004) and the second Protecting Vulnerable Children: A National Challenge (March 2005). Revelations about the suffering of children who migrated to Australia under imperial migrations schemes include work by Philip Bean and Joy Melville, Lost Children of the Empire (London and Sydney, 1989); Alan Gill, Orphans of the Empire: the shocking story of child migration to Australia (Milsons Point, NSW, 1998); and the autobiographical work by David Hill, The Forgotten Children: Fairbridge Farm School and its Betrayal of Australia's Child Migrants (Sydney, 2007).
} 
persists in having huge emotional force in the popular understanding of the adoption and post-adoption experience.

Adoption policy gradually came to reflect these shifts in attitudes. From the mid1970s all states and territories reviewed adoption legislation and embarked on initially cautious reversals of previous (secretive) practices throughout the 1980s. The right of adult adoptees to information about their origins, and to establish contact with their birth parents, slowly evolved. National Adoption Conferences, convened in Australia in 1976, 1978 and 1982, brought together people affected by adoption with professionals and researchers. These conferences served as important fora for activism and agitation on adoption law reform and also played a role in shifting public attitudes, due to media interest in the proceedings. ${ }^{10}$ The attitudes of social workers and adoption workers also shifted towards increased consciousness of the needs and rights of the biological mother (for example compulsory counselling and strict procedures to ensure genuine consent to adoption), as a corrective to what had gone before. Workers in the field began to tend towards the view that children should be with their biological parents where possible. These changes paralleled a decline in the numbers of children available for adoption, meaning that the principle that people wishing to be adoptive parents had a 'right to a child' was being challenged in a practical as much as a philosophical sense. Australia now has one of the lowest rates of domestic adoption in the western world. From its peak of nearly 10,000 a year in the early 1970s, domestic adoptions have dried up almost completely. ${ }^{11}$ From the time of the airlift of Vietnamese war orphans in 1975, inter-country adoption has gradually

\footnotetext{
${ }^{10}$ Marshall and McDonald, The Many-Sided Triangle, p. 41.

${ }^{11}$ See Patricia Hansen and Frank Ainsworth, 'Adoption in Australia. Review and Reflection', Children Australia vol. 31, 4 (2006), pp. 22-28.
} 
come to dominate the adoption landscape in Australia, although rates of intercountry adoptions into Australia remain low.

\section{The 2005 Report on Inter-Country Adoption}

Thus by the late 1990s, feeling against adoption seemed to be entrenched. How is it, then, that the recent report The Winnable War on Drugs: The Impact of Illicit Drug Use on Families (2007) can unflinchingly endorse legally enforced adoption as a policy option, not merely as a last resort, but as a 'default' response where parental illicit drug use is detected? Within the Australian context, the immediate catalyst for this shift is a 2005 report, also from The House of Representatives Standing Committee on Family and Human Services and also chaired by Bronwyn Bishop, into overseas adoption in Australia. ${ }^{12}$ This report opens up an unashamedly pro-adoption discursive space, subverting the expression "in the interests of the child" (previously the catch-cry of anti-adoption groups) to endorse not only intercountry adoption, but more tentatively to suggest that adoption, rather than foster care and other out-ofhome-care, might also be “in the best interests" of many Australian-born children. The committee therefore suggests (though it stops short of an official recommendation) an inquiry into domestic adoption practices, stressing that the dominant anti-adoption culture must be changed so that adoption in general might be regarded as a "legitimate way to form or add to families". ${ }^{13}$ As will be outlined below, the inquiry also reverses previous sentiment current since the 1970s revision and reform of adoption practices in privileging the needs and interests of adoptive

\footnotetext{
${ }^{12}$ House of Representatives Standing Committee on Human and Family Services, Overseas Adoption in Australia: Report of the inquiry into adoption of children from overseas, November 2005.

${ }^{13}$ Standing Committee on Human and Family Services, Overseas Adoption in Australia, p. 9.
} 
(heterosexual) parents, over birth parents. The inquiry represents a significant turning point in the history of attitudes to adoption in Australia.

The primary ostensible aim of the 2005 inquiry is to identify inconsistencies between the benefits and entitlements afforded to Australian families for birth (or biological) children, and those available to families for adopted children - as well as to identify inconsistencies between state and territory approval processes. The seemingly straightforward nature of the task of comparing state, territory and Commonwealth provisions and benefits meant that a short inquiry was envisaged. However, initial proceedings indicated that the complexity of issues and concerns surrounding intercountry adoptions necessitated a broader and more prolonged consideration. The unexpected scope of the resulting inquiry resulted - in part - from the large number of groups and individuals, chiefly adoptive parents, wishing to be heard on the matter. The Committee received 274 submissions and heard from people across Australia in both formal public hearings and informal community forums. But the Committee itself also found unexpected chords were struck within its members which drove the Committee as a whole towards a fuller investigation. Tasmanian MP Harry Quick became "so engrossed" in the inquiry that he travelled to China to personally visit orphanages, and it is clear that adoption became, during the course of the proceedings, a particular hobby horse for Bishop. ${ }^{14}$

\section{New attitudes to domestic adoption, and their international antecedents}

The Committee emerged from its proceedings, by its own admission, “unequivocally in support of intercountry adoptions as a legitimate way to give a loving family

\footnotetext{
${ }^{14}$ Ibid., p. x.
} 
environment to children from overseas who may have been abandoned or given up for adoption”. ${ }^{15}$ This generous endorsement is contrasted with the negative attitudes to adoption among the state and territory welfare departments responsible for processing adoption applications reportedly uncovered by the inquiry. These attitudes ranged “from indifference to hostility". ${ }^{16}$ It is this evidence of a "confronting anti-adoption attitude”, above all, that resulted in the inquiry stretching beyond its intended scope and ultimately working outside its terms of reference to encompass issues relating to local child protection and adoption. The committee observes that attitudes to domestic adoption colour official attitudes to intercountry adoption as well as child protection and out-of-home care. Thus, any consideration of intercountry adoption needed to address the meanings of adoption in its broad sense. ${ }^{17}$ It is acknowledged that the lack of support and resources for intercountry adoption are "part of the wider story of adoption in Australia generally". ${ }^{18}$

The first section of the report details the considerable change that has taken place in adoption over the past three or more decades, by which the number of adoptions per annum has declined to some five percent of the number in the early 1970 s. ${ }^{19}$ This decline is attributed to a number of factors, including increased access to contraception for women, the increase in labour force participation for women, and the accessibility of childcare. Another significant factor, on which the Committee dwells at length, is the "anti-adoption culture" that has arisen from the earlier, discredited adoption practices, which were marked by secrecy and frequently the coercion or duress of natal mothers: as detailed above, these practices affected both

\footnotetext{
${ }^{15}$ Ibid, p. ix

${ }^{16}$ Ibid., p. viii.

${ }^{17}$ Ibid., p. 1.

${ }^{18}$ Ibid., p. viii.
} 
indigenous and non-indigenous mothers and children. ${ }^{20}$ The committee refers to the findings of the Releasing the Past inquiry into past adoption practices (2000) and to submissions it received from relinquishing mothers who had endured the “unsympathetic” adoption practices of the 50s-70s. The complex relationship between the issue of the 'stolen generation' of indigenous children, and domestic adoption, is also acknowledged: it is observed that fears of a "White Stolen Generation" underpin criticisms of previous legislation designed to encourage longer-term placements for children. $^{21}$

The report observed a change in public and professional attitudes towards adoption since the 1970s, suggesting that it is the "entrenched" view of state and territory welfare departments that it is in a child's best interests to be reared by a biological parent, meaning that the focus of policy has tended to be “on the birth parents and a belief that children should maintain their biological links above all else”. ${ }^{22}$ The report challenges this attitude on the basis that the term "in the best interests of the child" is used as a "shield against any criticism of current adoption policy", leading to tens of thousands of children being placed in foster care and other forms of out-of-home care, despite research suggesting that “early, decisive intervention” to ensure stability is in the best interests of children. ${ }^{23}$

In these efforts to revise the role of adoption and the meanings attached to it, the Bishop Commission echoes some international trends in adoption policy, in evidence

\footnotetext{
${ }^{19}$ Ibid., pp. 1-2.

${ }^{20}$ On postwar adoption practice see Caroline Jones, 'Adoption - A Study of Post-war Child Removal in NSW', JRAHS Vol. 86, 1 (June 2000), pp. 51-64.

${ }^{21}$ Standing Committee on Human and Family Services, Overseas Adoption in Australia, p. 128.

${ }^{22}$ Standing Committee on Human and Family Services, Overseas Adoption in Australia, p. viii.

${ }^{23}$ Ibid., pp. ix, 126.
} 
in the both the United Kingdom and the United States. While in both of these jurisdictions adoption has never slumped to the low levels seen in Australia, researchers and commentators nonetheless agree that in the period from the 1970s, adoption has, for various reasons, emerged as 'problematic', particularly as an approach to the care of domestic babies and children who otherwise find themselves in serial foster-, short-term and other care arrangements. Reflecting on what appears to be a bias against adoption in the research literature, the legal scholar Elizabeth Bartholet asks, why, when "available evidence shows that adoption works extremely well for all those immediately concerned" is the "success story" of many cases of adoption "suppressed”? ${ }^{24}$ Similarly, Katarina Wegar documents strong anti-adoption biases in both the professional literature and attitudes of child-welfare and childplacement professionals. ${ }^{25}$

In both the US, through the Adoption and Safe Families Act (1997) (hereafter AFSA) and the UK, through the Adoption: A New Approach. White Paper (2000) and the Adoption and Children Act (2002), ${ }^{26}$ there is evidence of significant executive efforts to shift attitudes, policy and practice on adoption, particularly with respect to the adoption of domestic children, by questioning the relative desirability of the welfare objective of children remaining in a series of temporary placements with the view to them returning to their birth families, as distinct from their expeditious and permanent adoption. Both initiatives focus on clearing administrative and legal obstacles to domestic adoption, and like the Australian reports prepared by Bishop, call for a

\footnotetext{
${ }^{24}$ Elizabeth Bartholet, Family Bonds: Adoption, Infertility and the New World (Boston, 1999).

${ }^{25}$ Katarina Wegar, 'Adoption, Family Ideology, and Social Stigma: Bias in Community Attitudes, Adoption Research, and Practice’, Family Relations, Vol. 49, 4 (Oct. 2000), pp. 363-369.

${ }^{26}$ United States Congress, Adoption and Safe Familes Act (1997); see also Allen Harden, Fred Wulczyn and Robert George, Adoption from Foster Care: The Dynamics of the AFSA Foster Care
} 
refocusing of attention on adoption as a desirable outcome for children who may otherwise spend their lives in a series of short-term foster and other care situations. In both cases, as with the Australian reports, attention is directed away from the birth families and onto smoothing the way for those wishing to access children for adoption. In the case of each of these initiatives, the will of the executive is strongly present driving the moves for change, with both President Bill Clinton and, more particularly, Prime Minister Tony Blair associating themselves prominently with the move for reform.

Adoption: A New Approach and the Adoption and Children Act aim to expedite the legal, administrative and welfare processes for adoption in the interests of securing 'permanence' for children whose birth parents are unable to care for them, and assumed unlikely ever to be in a position to do so. Speed and permanence are the overriding objectives of the UK policy model: with a timeframe for children in continuous substitute care for the development of an adoption or "permanence" plan, which then must be "delivered promptly", with a "best interest" decision in each child"s case made within six weeks. The framework allows a further six months for an adoptive family to be actively sought out. ${ }^{27} \mathrm{New}$ Approach consistently subordinates other considerations to the two objectives of permanence and expedition. Even the priority given to issues of safety, while not overturned, is moderated in such areas as the allocation of resources and staff time to the permanence objective: "adoption has been given a lower priority than taking action to safeguard children in difficulty...the

\footnotetext{
Population (Chicago, 1999); and Secretary of State for Health, Adoption: A New Approach. A White Paper (London, 2000).

${ }^{27}$ Adoption: A New Approach, p. 24.
} 
need to find safe, permanent families for children is an intrinsic, long-term element in giving children a safe, fresh start and a new opportunity”. ${ }^{28}$

Children, it is asserted throughout the document, need permanence as much as they need safety and more than they need other factors, such as consanguinity or cultural continuity, in order to grow well and whole. The 'new approach' to adoption actively promotes a 'new' beginning, or a 'fresh' start for children whose families are unable to care for them and cites the words of one adoptee, Ahmed, by way of endorsing this approach: "I felt like my life was starting anew". ${ }^{29}$

Similarly, ASFA places emphasis on streamlining processes for placing children deemed 'at risk' in their families of origin and in various forms of state-supported substitute care into more permanent family situations. The legislation requires state child welfare agencies to "[focus their] attention... on the use of adoption as a route for children to leave state-supported substitute care”. ${ }^{30}$ As in the UK, permanence and expedition are key objectives of the US legislation, with a requirement that preadoption case planning, including legal action to terminate parental rights (TPR) and active recruitment of adoptive families, be initiated by state child welfare agencies as soon as a given child has lived in substitute care for 15 of the preceding 22 months. ${ }^{31}$ This is mandated in all cases, with limited exceptions.

There are key similarities between developments in the US, UK and those emerging in Australia, notwithstanding the different political contexts and the different histories

\footnotetext{
${ }^{28}$ Ibid., p. 8.

${ }^{29}$ Ibid., p. 6.

${ }^{30}$ Harden et al, Adoption from Foster Care, p. 1.

${ }^{31}$ Ibid.
} 
of adoption in each place. Notably, the socio-legal standard of the "best interests" of the child, up until recently held to lie in consanguinity and in the maintenance of family and cultural connections, is being deployed in quite a different way in the interests of English and American revisions to adoption, and the current Australian advocacy for such revision being generated through the House of Representatives Standing Committee on Family and Human Services and Bishop herself. Indicative of the way in which presumptions about adoption as the desirable policy option for children in troubled family circumstances operates, New Approaches outlines procedures for the development of a "best interests" assessment as a precursor to the development of an adoption plan. Within the terms of New Approach, it seems, one needs to find grounds for why adoption is not in the "best interests" of the child. In this the mobilisation of the "best interests" precept for particular policy outcomes closely parallels the effect of amendments to the Australian Family Law Act (2006) in its "rebuttable presumption” on shared and equal parenting being in the best interests of all children unless the court is satisfied otherwise. ${ }^{32}$ Equally indicative of the line of reasoning in New Approach and the particular model of adoption being promoted, the adoption plan is given the term, "Permanence Plan". Thus, it follows if permanence is good for children, and adoption offers permanence, adoption must be good for children. As indicated, the vision of adoption being offered in New Approaches deliberately revises thinking and practice on adoption in place since the reforms initiated in the 1970s and 80s. The vocabulary of the New Approach White Paper bristles with revisionist enthusiasm for adoption as providing 'clean breaks' from old (bad) birth families, and 'fresh starts' and 'new beginnings' for adoptees with their new families - once they can be found, that is. Every encouragement is to

\footnotetext{
${ }^{32}$ Sandra Berns, 'Mothers-in-law: lying down for the father again', Hecate, Vol. 31, 2 (2005), pp. 78-
} 
be given to prospective adoptive families, for whom certain bars - seen as providing unnecessary obstacles to 'permanence' for children - will be lowered.

The 2005 Bishop report suggests, as have similar reports in the UK especially, that current prejudice against adoption as a policy option is unwarranted, given that the “past social attitudes and practices that brought it about are no more”. ${ }^{33}$ With respect to intercountry adoptions, which are regulated by the international Hague Convention on Intercountry Adoption (to which Australia is a signatory) the Committee stresses that potentially relinquishing mothers receive counselling and every attempt is made to place children in their home countries before adoptive parents are sought elsewhere. It acknowledges, however, that children overseas may be available for adoption for reasons that "may reflect conditions in Australia one or two generations ago". This being the case, "it would not be in the interests of the child to refuse to provide them with a family environment in Australia if they cannot be adopted in their home country”. ${ }^{34}$ Bishop and her fellow committee members are conscious that any change in policy will rely on addressing attitudes to adoption. The Report recommends that the Commonwealth Minister for Family and Community Services should “develop a policy framework which acknowledges that adoption is a legitimate way of forming of adding to a family" which should result in better funding, better training, and a recognition that adoption practices have changed.

While acknowled ging that to claim that adoption is always the best option would be to repeat past mistakes, ${ }^{35}$ the report concludes that adoption - both domestic and

\footnotetext{
89.

${ }^{33}$ Ibid., p. 5.

${ }^{34}$ Ibid., pp. 5-6.

${ }^{35}$ Ibid., p. 131.
} 
intercountry - is underused in Australia, and makes recommendations geared to affecting change in this regard, at least in intercountry adoption. While they make no official recommendations regarding domestic adoption, the committee found enough evidence to "indicate that the states and territories should review their local adoption laws”. ${ }^{36}$ A substantial discussion of this matter appended to the report on intercountry adoption suggests that "an inquiry into local adoption practice could truly be 'in the best interests of the child"’ ${ }^{37}$

\section{Intercountry adoption and the needs of adoptive parents}

As noted above, intercountry adoption began in Australia with the close of the Vietnam War. 'Operation Babylift' brought almost 300 orphaned children to the country, and for the past fifteen years there have been roughly 300-400 intercountry adoptions per year, with most children coming from China (30\%), South Korea (26\%), Ethiopia (12\%), Thailand (11\%), India (8\%), and the Phillipines (11\%). ${ }^{38}$ In 2001 Audrey Marshall and Margaret McDonald observed that government attitudes to intercountry adoption in Australia tended towards ambiguity and even obfuscation, reflecting a "general uncertainty as to the wisdom of the process for the children involved, in transplanting them from one country and culture to another” as well as about whether it is the business of governments to facilitate and regulate the adoption of children from other countries. ${ }^{39}$

\footnotetext{
${ }^{36}$ Ibid., p. 124.

${ }^{37}$ Ibid., p. 132.

${ }^{38}$ Ibid., pp. 13-14, 36-39. Figures are for 2003-4.

${ }^{39}$ Marshall and McDonald, The Many-Sided Triangle, pp. 171-172.
} 
The 2005 inquiry displays none of this ambiguity. The Committee reports that “Intercountry adoptions can, without doubt, be in 'the best interest' of children”. ${ }^{40}$ Not only will these children “face a better future in a loving family in Australia than living in the street or in an orphanage in their country of origin”, but for many their adoption might mean "the difference between life and death" due to the conditions faced by abandoned and orphaned children in many countries. ${ }^{41}$ Evidence is proffered that intercountry adoptions are in general successful, especially where the child is young. $^{42}$

The reputed prejudice of social workers and state and territory welfare departments against domestic (and, by extension) intercountry adoption is, according to the report, most commonly displayed in a lack of positive action, rather than explicit opposition. It is acknowledged that this inaction is partly due to the fact that these departments focus resources on children and dysfunctional families within Australia. ${ }^{43}$ However, examples of outright opposition are also revealed, including instances where department representatives advised parents to donate money, or foster, rather than adopt. $^{44}$ These attitudes differ between jurisdictions: the ACT, South Australia and Tasmania are found to have the highest per capita rates of adoption in country and are reported to display positive attitudes towards the process, which for the Committee highlights "the importance of leadership attitude and belief in adoption as a legitimate way to form or add to families". ${ }^{45}$

\footnotetext{
${ }^{40}$ Standing Committee on Human and Family Services, Overseas Adoption in Australia, p. ix.

${ }^{41}$ Ibid., pp. x, 17.

${ }^{42}$ Ibid., pp. 15-16, 18.

${ }^{43}$ Ibid., p. 7.

${ }^{44}$ Ibid., p. 8.

${ }^{45}$ Ibid., pp. 8-9.
} 
Despite this acknowledgment of the good work being undertaken in some jurisdictions, the overarching representation of state and territory welfare departments in the 2005 inquiry is of powerful anti-adoption forces stacked against powerless prospective adoptive parents who had only the best intentions to give a family environment to children who would otherwise (in many cases) have a low life expectancy, remain institutionalised or live on the street. ${ }^{46}$ The Committee is particularly concerned with what it perceives as a "power imbalance" between prospective adoptive parents and departments and the resulting “[i]ntimidation of the intercountry adoption community" which meant that a number of potential adoptive were reluctant to speak to the inquiry for fear they might jeopard ise their applications to adopt. ${ }^{47}$ It is reported that staff sometimes displayed a "confronting anti-adoption attitude”, even extending to verbal abuse and threats, and that prospective adoptive parents feel powerless in their dealings with these departments. One official from NSW was reported as saying:

Parents have an agenda. They are desperate people and they believe it is their right to be able to do this, and it is not. No one has the right to adopt a child. You can have the altruistic view that we are a global society and we should be looking after all our children, and that is great. And we do it successfully, but we also make sure we do it damned right. ${ }^{48}$

Such attitudes, in the view of the Commission, meant that potential adoptive parents can not legitimately criticise departments, because accessing adoption services did not involve any guarantee of receiving a child. The Committee also expresses concern

\footnotetext{
${ }^{46}$ Ibid., p. 10.
} 
that laws prohibiting public discussion or publishing of the details of the parties to the adoption meant that adoptive parents are denied the right to protest. ${ }^{49}$ Long delays in the process of adoption ${ }^{50}$, the low adoption rate in Australia, and the hostility faced by the adoption community are viewed by the Committee as evidence that these departments are abusing their “gatekeeping” role: overstretched budgets and resources are not considered to be acceptable excuses. The Committee reports itself to be pleased to "take on" the task of making government officials involved in intercountry adoption accountable. ${ }^{51}$

The unquestionably good intentions of adoptive parents or prospective adoptive parents are presented quite uncritically as being in a sense timeless, disinterested and free of ideology or the influence of any factors other than the desire to provide a loving “family environment to the children overseas who have been abandoned or put up for adoption”. ${ }^{52}$ State and territory welfare departments, on the other hand, are represented as fickle and prone to unthinkingly follow the latest fad or trend in social science research. It is suggested that these departments have a history of "swinging between extremes” on adoption. ${ }^{53}$ The current anti-adoption culture found in these departments is seen as reactionary, a "swing back from the stolen generation pendulum" ${ }^{54}$ rather than a reasoned position based on the “interests of the child”. Although it is acknowledged that "Both adoptive parents and departmental officials

\footnotetext{
${ }^{47}$ Ibid., p. 9.

${ }^{48}$ Ibid., p. 12.

${ }^{49}$ Ibid., pp. 111-115. See also Georg ie Oakshott, 'Against the Odds', About the House (Nov. 2005), pp. 38-41.

${ }^{50}$ This issue has received some recent media attention: see for example transcript of Stateline Western Australia story 'Overseas adoptions and the long wait for parents in WA', 3 November, 2006 at http://www.abc.net.au/stateline/wa/content/2006/s1784733.htm

${ }^{51}$ Standing Committee on Human and Family Services, Overseas Adoption in Australia, pp. 9-12.

${ }^{52}$ Ibid., p. 10.

${ }^{53}$ Ibid, p. 6.
} 
claim that they are acting in “' the best interests' of children”, the Committee judges that the expression is "used as a mantra by bureaucracy to justify the dominant antiadoption culture". ${ }^{55}$ Pro-adoption groups are not seen to have a vested interest in “justifying” anything in their use of the expression. There are interesting parallels here with recent debates about the intervention of the federal government to address the sexual abuse of children in Aboriginal communities in the Northern Territory. Anyone daring to criticise the details of the government's plan, or to raise the possibility of another stolen generation, is accused of politicising the care of children. ${ }^{56}$

The Committee's terms of reference mean that particular emphasis is laid on inquiring into any discrimination against adoptive parents in terms of the benefits and entitlements accorded to biological parents. The Committee, through their recommendations, seek to put adoptive parents and biological parents “on an equal footing” in terms of benefits such as maternity/paternity leave entitlements and the maternity (Baby Bonus) payment. ${ }^{57}$ It is stressed that the discrimination it uncovered in this regard was indirect in nature. ${ }^{58}$ This discrimination was however seen to be implicit not only in benefits and entitlements, but also in the application process, the high financial cost of adoption, and the kinds of surveillance to which adoptive parents (as against biological parents) are subjected. For example, it is noted that some adoption authorities require adoptive parents to take contraceptive measures for

\footnotetext{
${ }^{54}$ Ibid., p. 125.

${ }^{55}$ Ibid., p. 10.

${ }^{56}$ See for example Miranda Devine, 'The Madness of the Critics', The Sydney Morning Herald, 28 June 2007, at http://www.smh.com.au/news/opinion/the-madness-of-thecritics/2007/06/27/1182623988896.html

${ }^{57}$ Standing Committee on Human and Family Services, Overseas Adoption in Australia, p. 74, also see ch 4.

${ }^{58}$ Ibid., p. 69.
} 
up to 18 months after the adoption. It is observed that "biological parents manage these natural aspects of life" themselves and “no-one suggests...that govts should regulate how biological parents manage these risks”. ${ }^{59}$

The requirement of the inquiry to compare benefits accessible by adoptive parents, to those available to biological parents, and also the attention to matters of application processes (which by their nature raise the issue of who should be allowed to parent) appears to have encouraged - especially among the submissions - a pitting of adoptive parenthood against biological parenthood. Australian Families for Children submitted a detailed table showing discrepancies in the cost of becoming a parent, as well as eligibility to be a parent, to highlight inconsistencies in this regard. ${ }^{60}$ Other submissions draw attention to the fact that the cost of adoption was borne largely by parents, whereas the cost of bearing biological children (and some of the cost of reproductive technologies like IVF) was borne largely by the state. ${ }^{61}$ At least one submission refers to the pronatalist rhetoric of the Howard government, suggesting that the high fees charged for intercountry adoption might suggest an element of racism. ${ }^{62}$ It is noted that adoptive parents in the US enjoy tax breaks and other financial incentives: this is acknowledged by the Commission, which does not however recommend tax deductions. ${ }^{63}$

In the process of these comparisons between adoptive and biological parenting, their respective costs, the degree of intervention experienced by parents, and the like,

\footnotetext{
${ }^{59}$ Ibid., p. 58.

${ }^{60}$ Standing Committee on Human and Family Services, Overseas Adoption in Australia, Submission 17, at http://www.aph.gov.au/house/committee/fhs/adoption/subs/sub017.pdf

${ }^{61}$ Ibid., for example submission 1 , at http://www.aph.gov.au/house/committee/fhs/adoption/subs/sub001.pdf

${ }^{62}$ Ibid., Submission 3, at http://www.aph.gov.au/house/committee/fhs/adoption/subs/sub003.pdf
} 
deeper tensions regarding community attitudes towards adoptive parenthood emerge. Parents appear acutely sensitive to any suggestion on the part of government departments that adopted children were "not theirs". ${ }^{64}$ Medicare is singled out for failing to make adoptive parents “feel like parents” as a result of their policy of listing adoptive children on a different Medicare card from that of the parent, in case the adoption breaks down. Similar problems were encountered in dealings with various staff in attaining passports for children. ${ }^{65}$ It is remarked in one submission from an adoptive mother that referring to birth parents as "natural” parents on official government documents like the census marks the adoptive parent as an “UNNATURAL” parent. ${ }^{66}$ The Committee stresses the need for sensitivity and empathy in this regard, but is also apparently careful to avoid any suggestion of a return to previous secretive adoption practice/discourse. For example, it is stressed that suggestions that adopted children should be given new, local birth certificates are “not to hide the adoption”, but to give a "single, widely recognised document” to affirm their birth details and adoption to parents. ${ }^{67}$

The Committee makes a number of recommendations designed both to remove any discrepancies between adoptive and biological parents in regard to entitlements, and also to improve the efficiency and accessibility of intercountry adoption. It is recommended that the Commonwealth-State Agreement governing intercountry adoption be renegotiated and that the Commonwealth take a more active role, particularly in the development of new programs. ${ }^{68}$ The Committee also seeks to

\footnotetext{
${ }^{63} \mathrm{Ibid}$., for example Submissions 3; see report pp. 79-80.

${ }^{64}$ Ibid., for example pp. 85-86.

${ }^{65}$ Ibid., pp. 84-87.

${ }^{66} \mathrm{Ibid}$., Submission 19, at http://www.aph.gov.au/house/committee/fhs/adoption/subs/sub019.pdf

${ }^{67}$ Ibid., p. 82.

${ }^{68}$ Ibid., pp. 34, 109.
} 
make processing of applications more efficient, accountable and harmonised among jurisdictions. They recommend that screening and assessment work should be handed over to accredited non-government organisations - as has been done in overseas jurisdictions. ${ }^{69}$ In addition, they pledge money to establish a national peak overseas adoption support group, finding that pro-adoption groups, in contrast to post-adoption support groups for relinquishing mothers, do not receive public funding. ${ }^{70}$

\section{The politics of adoption}

As an extension of these recommendations, the 2005 Bishop report also calls for a more "principle-guided approval process" focused on factors directly related to the probable success of the adoption, as a response to complaints that arbitrary tests (such as age and Body Mass Index) are used to judge the capacity of potential adoptive parents. ${ }^{71}$ These questions of eligibility and capacity to parent do not, however, extend to questions of marital status, and whether single people or same-sex couples were likely to be successful parents. The inquiry’s championing of adoptive parents against obstructive welfare departments and self-interested social workers is only applicable to married, heterosexual adoptive parents. In the context of the conservative family values of the Howard government, in which the Prime Minister has made it clear that he does not support adoption by same-sex couples, and the Federal government has moved to make it impossible for same-sex couples to adopt from overseas ${ }^{72}$, the revision of attitudes to adoption does not extend to any revision of who might be considered eligible to adopt. So while Bishop and her colleagues are keen to revise notions of family to the extent that adoption is viewed as a "legitimate

\footnotetext{
${ }^{69}$ Ibid., see pp. ix, xvii-xxi.

${ }^{70}$ Ibid., pp. xxi, 121-122.

${ }^{71}$ Ibid., p. 59.
} 
way” to make or add to family, the idea of family itself remains unchallenged and unquestioned. Only heterosexual couples in “typical family arrangements" have access to the limited number of children available. ${ }^{73}$

Recent historical work has shown that adoption policy and wider attitudes to adoption reflect changes in dominant ideas about family, and about women and motherhood. ${ }^{74}$ Other commentators have remarked on the capacity of adoption to subvert, and innovate changes to, the social construction of motherhood and kinship. ${ }^{75}$ While the shift in policy direction on adoption in Australia embodied in the 2005 inquiry can be likened to the modernising 'third way' taken by the Blair government in adoption policy, in Australia the swing back towards adoption as a policy option has not involved any serious engagement with progressive questions relating to the family and the diverse forms it may take, as has taken place in Britain. ${ }^{76}$

Instead, this renewed focus on adoption has been spearheaded by moral conservatives, reflecting a climate in which these groups have taken the lead in determining discourse around adoption, as part of a broader politicisation of the family in Australian public life. The conservative discursive monopoly on adoption in Australia

\footnotetext{
72 The Marriage Legislation Amendment Bill, 2004, in addition to defining legal marriage in Australia as the union of a man and a woman, prohibited intercountry adoption by same-sex couples.

${ }^{73}$ 'PM rejects gay adoption', Herald Sun, 8 June, 2007, at http://www.news.com.au/heraldsun/story/0,21985,21870485-661,00.html; 'Ban on gay couples adopting from overseas', Herald Sun, 2 August, 2007, at http://www.news.com.au/heraldsun/story/0,21985,22178311-661,00.html

${ }^{74}$ See Julie Berebitsky, Like Our Very Own: Adoption and the Changing Culture of Motherhood, 1851-1950 (Lawrence, Kansas, 2000); E. Wayne Carp (ed.), Adoption in America: Historical Perspectives, (Ann Arbor, 2002); Judith S. Modell, Kinship with Strangers: Adoption and Interpretations of Kinship in American Culture (Berkeley, 1994) and A Sealed and Secret Kinship: the Culture and Policies and Practices in American Adoption (New York and Oxford, 2002).

${ }^{75}$ For example Shelley M. Park, 'Adoptive Maternal Bodies: A Queer Paradigm for Rethinking Mothering', Hypatia, Vol. 21, 1 (Winter 2006), pp. 202-226; Sarah-Vaughan Brakman and Sally J. Scholz, 'Adoption, ART, and a Re-Conception of the Maternal Body: Towards Embodied Maternity', Hypatia, Vol. 21, 1 (Winter 2006), pp. 54-73.
} 
reflects the ways in which adoption, despite its potential to destabilise dominant or essentialist ideas about family and kinship, as well as womanhood and motherhood, has historically operated to bolster prevailing social ideals in these areas. As Julie Berebitsky has shown, adoption as it developed in Western countries came to mirror the ideal contemporary conservative family and also helped to define this ideal. Despite - or perhaps because of - adoption's status as a site on which “the culture at large thrashed out the meanings of family and parenthood”, it has been, and continues to be, understood in dominant discourse as a way for infertile, middle class heterosexual couples to create a nuclear family, paralleling the 'natural' family as closely as possible. ${ }^{77}$ While adoption is an issue that has multi-faceted political expediency, its more radical implications and possibilities are often trumped, and the catch-cry "in the interests of the child" used to disguise the politicised nature of this conservative appropriation.

This tendency for the radical political and social potentiality of adoption to be muted through its capture and containment within dominant (conservative) discourse around family and motherhood has been amply illustrated in the United States, where adoption has long been discursively utilised by the religious right (despite the fact that other parties fighting for adoption include prospective single parents and same-sex couples) as a response to the problems of abortion and teenage pregnancy, and where the (conservative) adoption lobby is politically powerful. ${ }^{78}$ Adoption is easier to

\footnotetext{
${ }^{76}$ See Pringle, 'Adoption in Britain: Reflexive Modernity?'

${ }^{77}$ Berebitsky, Like Our Very Own, pp. 2-3.

${ }^{78}$ See Katarina Wegar, Adoption, Identity, and Kinship: the Debate over Sealed Birth Records (New Haven and London, 1997), p. 128.
} 
achieve in the US - it was reported recently that married actors Deborra- lee Furness and Hugh Jackman travelled to the US to adopt, to avoid Australian red tape ${ }^{79}$.

Commentators agree that in the decade since it first took office, the Howard government has taken an increasingly conservative stance on all aspects of policy and practice: economic, industrial, social, and most recently moral. ${ }^{80}$ The trajectory of Bishop’s parliamentary career reflects this wider movement. Her maiden speech in 1987 announced her as a seeker after freedom, in fact " four freedoms: the freedom of the individual, the freedom of choice, the freedom to pursue excellence and the freedom to seek reward for effort”. All four quickly resolved into economic freedom - the search for “free-er trade”. ${ }^{81}$ Before the Howard Government won office in 1996 Bishop was seen as a prominent and conservative 'Dry' and a potential successor to Howard $^{82}$, but as others consolidated their claims she sank from public view. In recent years her energies have been directed largely to family-oriented social and moral concerns, as the Chairman of the House of Representatives Standing Committee on Human and Family Services.

While identified as a strong Conservative who positions herself on the right of her party, Bishop is not publicly aligned with the group who are credited with bringing family concerns into the government's social policy. The Lyons Forum is (or was) a coalition of Christian parliamentarians of all denominations - Catholic through to splinter groups of Protestants - though always of the fundamentalist variety. From

\footnotetext{
${ }^{79}$ Ellen Connolly, 'Furness to Lobby on Adoption', The Daily Telegraph, 12 August, 2007, at http://www.news.com.au/dailytelegraph/story/0,22049,22227778-5006009,00.html?fro m=public rss

${ }^{80}$ Marion Maddox, God Under Howard: The Rise and Rise of the Religious Right in Australian Politics, (Sydney, 2005).
} 
2004 it included a parliamentary representative of Australia’s first explicitly religious political party, Family First, whose origins are in the pentacostal Assemblies of God. ${ }^{83}$ The central tenets of the group are: "We believe that the family is the Godordained fundamental unit of society"; and "We believe that government through its activities should promote the family as the fundamental unit of society”. ${ }^{84}$ Under this capacious umbrella members have advocated the full range of moral crusades familiar across Europe and America, against all those forms of living and loving not encompassed in heterosexual marriage and unrestrained reproduction. The achievements of the Forum to date include tighter forms of censorship, explicit prohibition of gay marriage, restricting access to reproductive technology by marital status, the watering down of affirmative action, and changes to the tax structure favouring married women who do not work. ${ }^{85}$ As we shall see, the most prominent member of the Forum, Health Minister Tony Abbott, was thrust into the adoption debate in 2005 and attempted to use this to drive his anti-abortion position, and Bishop’s adoption inquiry wholeheartedly embraced the proposition that the heterosexual family was the fundamental unit of society. Though not endorsing the proposal put by the evangelical Festival of Light - that adoption should only be available to "husbands and wives who have been married for at least three years” ${ }^{86}$ it ignored submissions from gay and lesbian reform groups calling for the inclusion of single-sex parents as prospective adoptees (a measure already in place in three

\footnotetext{
${ }^{81}$ The Hon Bronwyn Bishop MP, Member for Mackellar (NSW), First Speech To Parliament, 16 September, 1987, at http://www.aph.gov.au

${ }^{82}$ Maddox, God Under Howard, p. 40.

${ }^{83}$ unbelief.org, 'Exposing the Religious Right in Australia', at http://unbelief.org/

${ }^{84}$ Maddox, God Under Howard, p. 66.

${ }^{85}$ Ibid., p. 73.

${ }^{86}$ Standing Committee on Human and Family Services, Overseas Adoption in Australia, Submission 150, at http://www.aph.gov.au/house/committee/fhs/adoption/subs/sub150.pdf
} 
Australian states). ${ }^{87}$ As we have seen, the heroes of the report were instead the “loving [heterosexual] families" who were ready to take in "children from overseas who may have been abandoned or given up for adoption”. ${ }^{88}$

Adoption did not appear as an issue on the agenda of the Australian Christian Right until late January 2005, when “a powerful alliance of religious leaders” called for a range of measures to prevent abortion. ${ }^{89}$ Adoption was presented as a solution to the abortion problem; pregnant women were to be advised of the virtues of adoption in a compulsory counselling session that was to be made a condition of Medicare funding for termination. ${ }^{90}$ Abortion was and is an issue of great concern to fundamentalist churchmen in Australia, especially to the Catholic hierarchy and its front organisations like the Right to Life Assocation, but federal parliamentarians of all parties had avoided any public discussion of the divisive issue for almost thirty years. ${ }^{91}$ The appointment of Tony Abbott as Minister for Health in 2004 gave the churches some hope. Abbott, a very public Catholic and member of the Lyons Forum, had been airing the iniquities of abortion both inside parliament and out ever since his election in 1994. He made a well-publicised attempt in November 2004 to mount a public debate on the topic, but failed to win any consistent support.

In February 2005 Abbott worked with other members of the Lyons Forum to publicise the measures proposed by the religious alliance. They met with little success; women parliamentarians from all parties declared that Australia didn't need a debate on

\footnotetext{
${ }^{87}$ Ibid., Submission 216, at http://www.aph.gov.au/house/committee/fhs/adoption/subs/sub216.pdf; Submission 231, at http://www.aph.gov.au/house/committee/fhs/adoption/subs/sub231.pdf

${ }^{88}$ Ibid., p. ix.

${ }^{89}$ Religion \& Ethics Australia Digest, No. 022 (28 Jan-3 Feb 2005).

${ }^{90}$ Editorial, Sydney Morning Herald, 3 February, 2005, p. 16.

${ }^{91}$ Maddox, God Under Howard, p. 103.
} 
abortion, and Prime Minister Howard said that he did not support any proposal to limit women's access to Medicare funding for abortions. ${ }^{92}$ And then on February 21 Abbott produced his trump card - he announced that he had been contacted by a son whom he had given up for adoption 27 years before. ${ }^{93}$ The resulting "radio and television frenzy” ${ }^{94}$ produced headlines like “Overjoyed Abbott pleads case for adoption” ${ }^{95}$, and “Adoption in the spotlight after Tony Abbott reunites with son”. ${ }^{96}$ Feminist commentator Anne Summers protested that Abbott was manipulating the media; “Abbott pleaded for people not to use his son in the abortion debate, thus making the link himself. He did not have to say this. He did not have to say anything”. ${ }^{97}$ Enraged bloggers all over the world agreed with her. But Abbott’s amiable $^{98}$ son - who reportedly greeted Abbott with the words “Thanks for having me”99 - was living evidence of the virtue of the adoption solution.

None of this ideological work was undone by the revelation later in March that DNA testing had proved that the young man in question was not in fact Abbott's son ${ }^{100}$ Abbott went on to set up a new federal program of counselling for women with

\footnotetext{
92 John Howard, Prime Minister, February 1, 'I think we've got it right in Australia in that women throughout Australia who sadly and unfortunately find themselves in a situation of needing an abortion have it supported with Medicare funding. I support that.' Sydney Morning Herald, 3 February 2005, p. 2.

${ }^{93}$ Damien Murphy, Alan Mascarenhas and Mark Metherell, 'Overjoyed Abbott pleads case for adoption', Sydney Morning Herald, 22 February 2005. Abbott had in fact been contacted with the news on 26 December 2004.

${ }^{94}$ Anne Summers, 'Abbott's tale is grubbier than it seems', Sydney Morning Herald, 25 February 2005, at http://www.annesummers.com.au/

${ }_{95}$ Murphy et al, 'Overjoyed Abbott pleads case for adoption'.

${ }^{96}$ Australian Broadcasting Commission, The World Today, Monday, 21 February, 2005, at http://www.abc.net.au/worldtoday/content/2005/s1307495.htm

${ }^{97}$ Summers, 'Abbott's tale is grubbier than it seems'.

${ }^{98}$ If somewhat reluctant. Daniel O’Connor's newly discovered mother reported that 'he swore profusely when he found out who his father was. A pony-tailed young man described by his friends as “a bit of a hippie”, he could not be more different from Mr. Abbott.' Kathy Marks, 'Minister discovers son he gave up for adoption right under his nose', The Independent, London, 22 February, 2005.

${ }^{99}$ Damien Murphy, 'Abbott’s love story turns into shaggy dog story', Sydney Morning Herald, 22 March, 2005, at http://www.smh.com.au/news/National/Abbotts-love-child-turns-into-shaggy-dogstory/2005/03/21/1111253960197.html 100 Ibid.
} 
'unintended pregnancies', the development and implementation of which he entrusted to pro-life Catholic counselling agencies. ${ }^{101}$ An official announced that the counselling would be properly balanced; “The three options facing women - abortion, adoption, and keeping the baby - would be given equal weight”. ${ }^{102}$ Undeterred by furious opposition from women's groups and calls to resign from the opposition parties, Abbot told the National Press Club that the furore was worth it. "If these initiatives help women to make genuine personal choices rather than sociallyconditioned ones; if they help women in an almost impossibly difficult situation to feel less alone, they will ultimately be one of the Howard Government's more significant achievements”. ${ }^{103}$

Maryanne Dever has recently assessed the family policies of the Howard government with an eye to the representations of motherhood which they embody. ${ }^{104}$ She finds that “a marked tension over who constitutes 'proper families', 'correct' mothers, and the right (white) babies", is resolved in practice by the work of "reconsitut(ing) familiar heirarchies of meaning and merit in the realms of motherhood and the family”. ${ }^{105}$ Those familiar heirarchies are those of class and race; white middleclass mothers and families are always right. Space precludes us from considering here the issue of race as it bears upon current adoption policy; perhaps here the social construction of families necessarily embracing difference may offer the chance of liberatory transformation. But Dever's heirarchy of class is quietly dominant in the

\footnotetext{
101 'Support for pregnancy services', Press release from Mr Abbott's office, 4 November 2005, at Archived Press Releases, www.health.gov.au

102 Jewel Topsfield and Jill Stark, 'Abbott in pregnancy advice row', The Age, 3 January, 2007, at http://www.theage.com.au/articles/2007/01/02/1167500124318.html

${ }^{103}$ Tony Abbott, 'Address to the National Press Club', 2 August 2006, at http://www.tonyabbott.com.au

${ }^{104}$ Maryanne Dever, 'Baby talk: the Howard Government, Families, and the Politics of Difference', Hecate, Vol. 31, 2 (October 2005), p. 45-61.

${ }^{105}$ Ibid., p. 45.
} 
making of meaning within the Bishop report, and its effect is to revive the past, not to foreshadow the future. The report was quite unapologetic in stating that most adoptive parents have a middle class, professional background, and in expressing its view that “adopting a child into a family with a high income and good education is likely to have positive effects on that child’s tertiary education and its marital status”. ${ }^{106}$

\section{Conclusion: full circle}

The 2005 and 2007 inquiries anticipate a full circular return to an understanding of adoption within a moral framework focusing, inevitably, on bad mothers. ${ }^{107}$ Debates about adoption have always been woman-focused: while the meanings of family are always at stake in discussions about adoption, the meaning of motherhood is never far from the surface. The brutality of earlier adoption practices may be attributed partly to the perception of a moral taint in connection with illicit female sexuality. Unmarried mothers were depicted as being bad and undeserving of the child, not merely as a result of their 'sin', but due to the fact that, lacking a husband, they could not afford to give their child the best start in life. Many mothers who gave up children did so because they were persuaded it would be selfish not to allow the child a 'good' home.

Selfish birth parents (with discussion focusing on mothers) make a reappearance in Bishop’s 2005 report, in the discussion of foster care: parents are reported to be "reluctant to give up children when the foster system relieves them of the responsibility of looking after them”. ${ }^{108}$ While birth mothers are otherwise virtually invisible in the Bishop report (due to the focus on overseas adoption), in content and

\footnotetext{
${ }^{106}$ Standing Committee on Human and Family Services, Overseas Adoption in Australia, p. 5.

107 See Katarina Wegar, 'In Search of Bad Mothers: Social Constructions of Birth and Adoptive Motherhood', Women's Studies International Forum, Vol. 20, 1 (1997), pp. 77-86.

${ }^{108}$ Standing Committee on Human and Family Services, Overseas Adoption in Australia, p. 125.
} 
emphasis the report can be understood as signalling a shift in the representation of the parties to adoption, in which the birth mother is no longer the focus of sympathy that she has been in the past twenty years, and the adoptive mother no longer plays "the least attractive” role in the adoption triad. ${ }^{109}$ Adoptive mothers dominate the submissions received by the committee, and the sympathy of its members, in a way that excludes consideration of the circumstances and needs of birth mothers and privileges adoptive mothers as good prospective parents. It is interesting to observe that adoptive mothers giving evidence to the 2005 Bishop inquiry draw on constructions of motherhood that Berebitsky observed among adoptive parents in the 1920s in the US: constructions in which (morally-infused) "conscious choice and conscientious care replaced instinct and intuition”. ${ }^{110}$

Selfish birth mothers also feature in the 2007 Bishop report, in the context of an explicit effort to make illicit drug use a moral issue. The report opens with the contention that policies around drug use needed to be "based on higher principles and morality" that recognise vulnerable children as the "hidden victims of illicit drug use”. ${ }^{111}$ Bishop's particular targets in this case are the “drug industry elites”, supporters of harm minimisation policies including various drug education bodies, service providers and academics, who in her view take an “amoral” stance on drug use (which paints it as neither 'good' or 'bad' and questions the effectiveness of the federal government’s 'war on drugs') as against a stance which recognises drug use as

\footnotetext{
${ }^{109}$ Denise Cuthbert, 'Stolen Children, Invisible Mother and Unspeakable Stories: The Experiences of Non-Aboriginal Adoptive and Foster Mothers of Aboriginal Children’, Social Semiotics, Vol. 11, 2 (2001), p. 141.

${ }^{110}$ Berebitsky, Like Our Very Own, p. 84. This reinvigoration of older discourses about the superiority of adoptive over biological parenthood has been echoed more recently and confoundingly in feminist re-theorisations of adoption which hold up adoption as an exemplary site for an embodied critique of essentialised motherhood. See Denise Cuthbert, Kate Murphy, and Marian Quartly, 'White Papers, Queer Mothers, Poor Girls and their Babies: strange new alignments and familiar old occlusions in the discourses of 'new adoption', as yet unpublished paper 2007.
} 
being immoral insofar as it affects families and children, who according to the report are at risk of child abuse, neglect, sexual assault and intergenerational cycles of drug use. It is within this framework that Bishop again reiterates her 2005 criticisms of state welfare departments that "force children to be with their biological parents as their preferred policy", meaning that the "interest of the child is not the dominant issue”. ${ }^{112}$ It is suggested that drug-addicted mothers only want their children returned from foster care because of the money they bring - "the family support payments that move with the child”. ${ }^{113}$ These undeserving and immoral drug-addicted mothers are contrasted with the many deserving, drug-free prospective adoptive parents out there: “[m]eanwhile, there are many people who would like to establish or add to a family but are unable to have children of their own”. ${ }^{114}$ It is observed that valuable time - in terms of child development - is lost while child protection authorities wait for parents to recover from drug addiction: time in which children could be in new, stable homes. ${ }^{115}$ As in international examples of new adoption policy, expedition of the adoption process is seen to be in the best interests of child/ren - speed and permanence being the overriding objectives, as in the UK and US policy models.

Bishop’s efforts to (re)situate drug use within a moral framework, then, and her related efforts to restore adoption as a legitimate policy option in response to the impact of illicit drug use on children, represents a return to an older understanding of adoption within a moral framework focusing, as ever, on female behaviour. Sexual behaviour even makes a reappearance: it is observed that “female drug users are more

\footnotetext{
${ }^{111}$ Standing Committee on Human and Family Services, The Winnable War on Drugs, p. ix.

${ }^{112}$ Ibid., p. xi.

113 Ibid., p. xii.

114 Ibid., p. 83.

${ }^{115}$ Ibid., pp. 71-83.
} 
likely than the general population to engage in high-risk sexual behaviours, including having sex with multiple partners, and not asking partners to use condoms”. ${ }^{116}$

While the current emergence of discourses which are pro-adoption/pro-adoptive parenting represents a significant and perhaps surprisingly rapid historical shift, two factors make it explicable. One is the recent international move towards a revival of the fortunes of adoption as a prefered policy option, which recent Australian revisionist statements on adoption clearly echo. The other is the tendency, in the history of adoption, for one type of parenting to be privileged at any given moment, so that biological parenthood (especially motherhood) is pitted against adoptive parenthood (again, especially motherhood), due in large part to the political and ideological utility of binary oppositions. Australian conservatives have harnessed this binary utility in the service of a broader moral project which pits a nineteenth century ideal of heterosexual marriage and family against the fluidity of sexual identity in the twentyfirst century.

${ }^{116}$ Ibid., pp. 87-88. 